\title{
Augmented reality applications in product design process
}

Damla Şahin*

Abdullah Togay,

Suggested Citation:

Abstract 
1. Introduction 
2. Augmented Reality

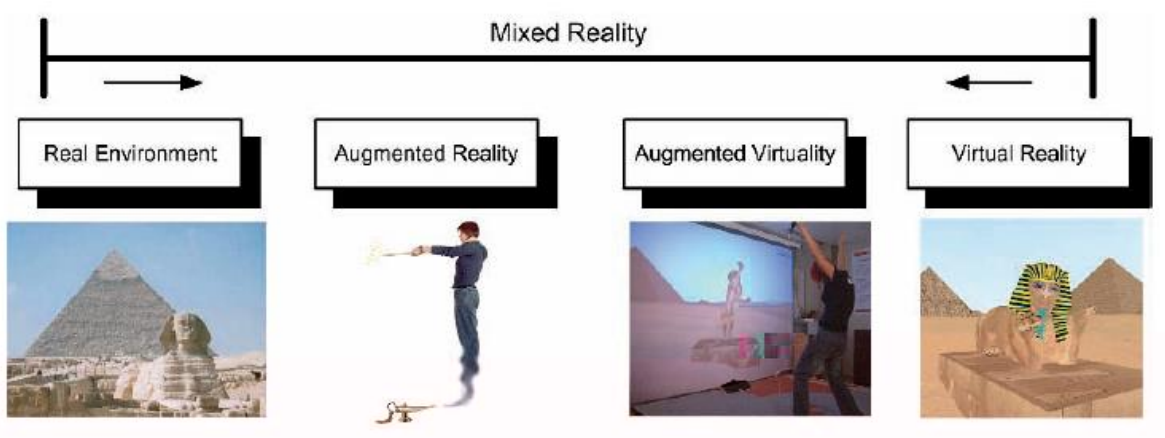



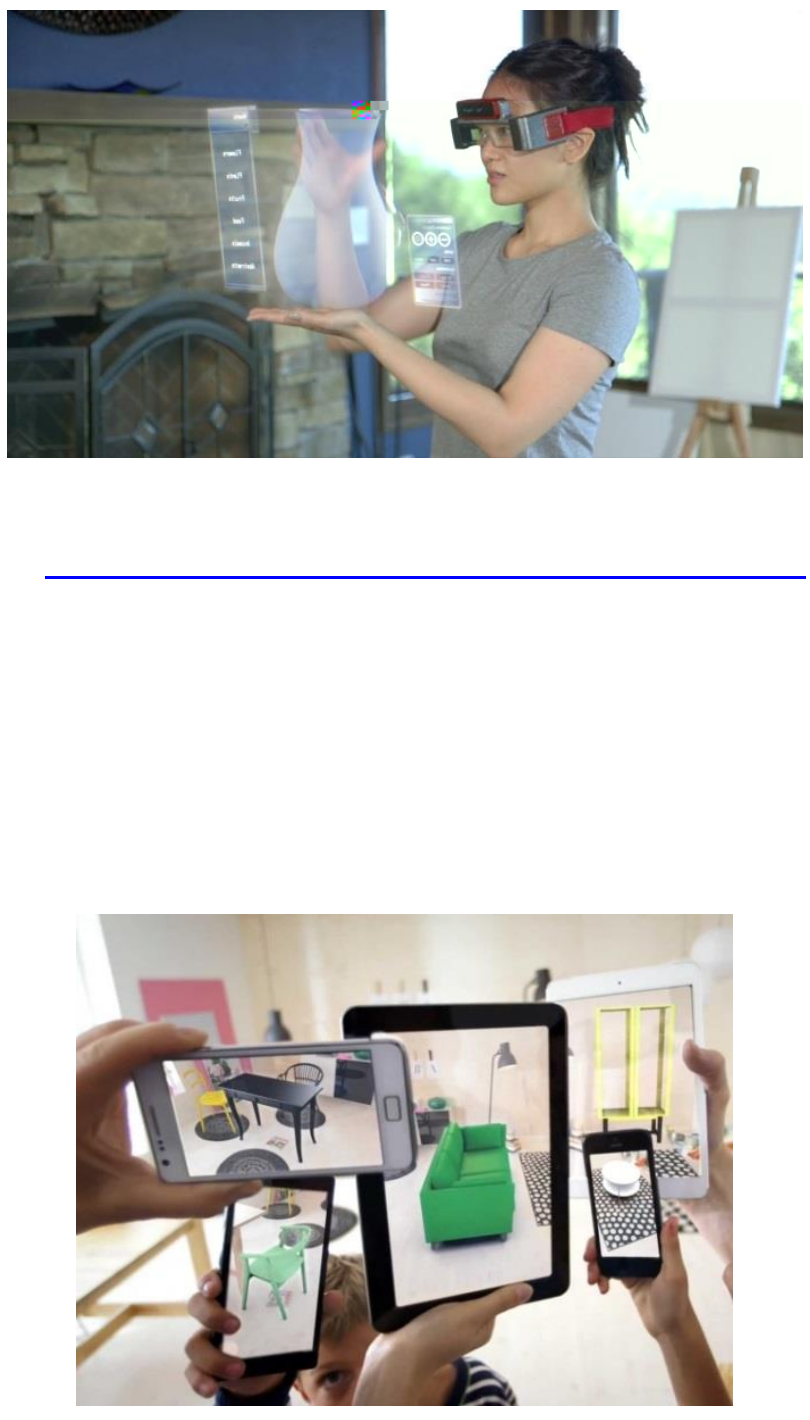


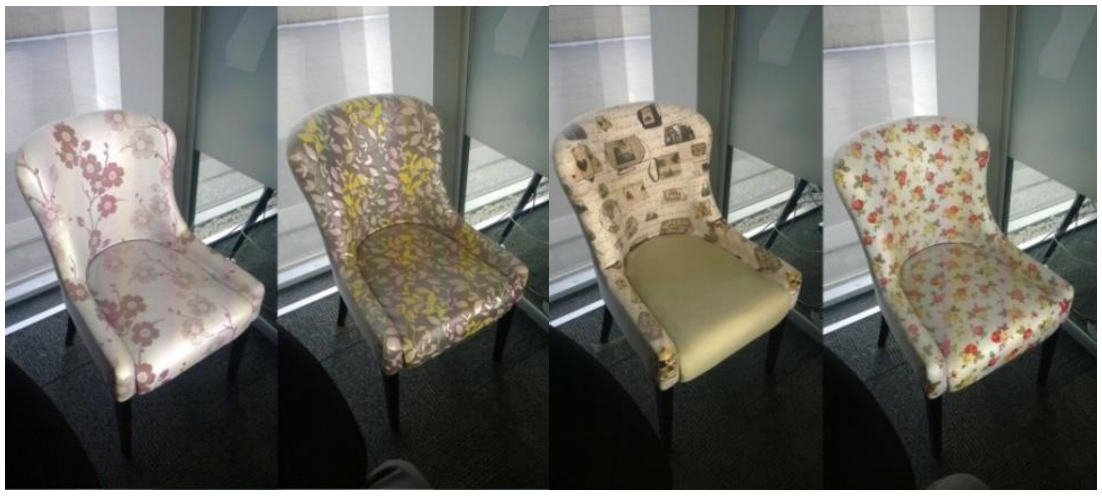


3. Fieldwork

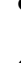

$\bullet$

$\bullet$ 


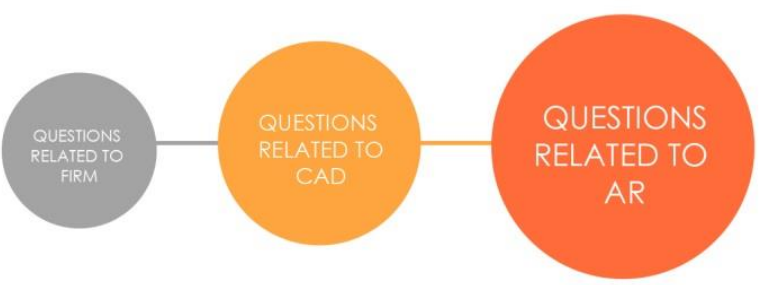


4. Findings

D 
5. Conclusion and Future Work 
Acknowledgements

References 

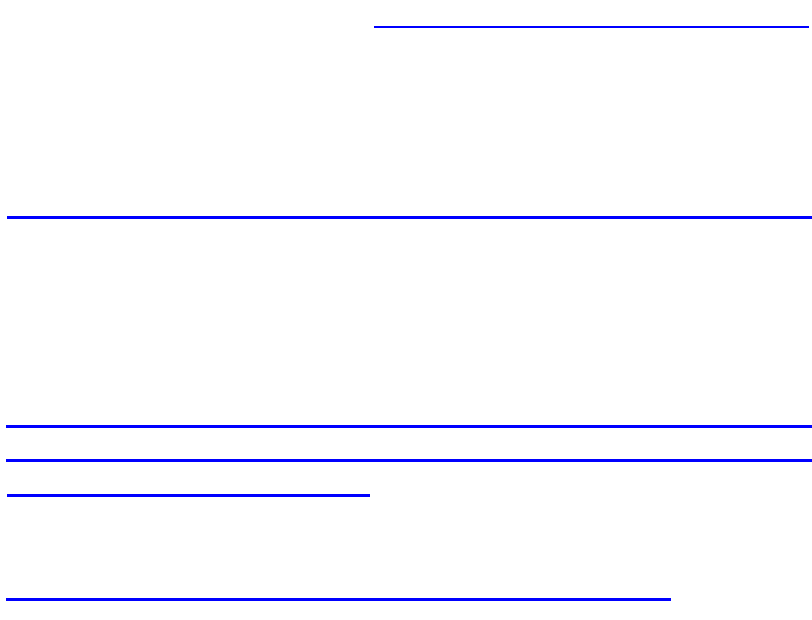